\title{
on_education
}

Journal for Research and Debate

\section{editorial: exploring the relationship of money and education}

\author{
On Education
}

In capitalism, the significance of both money and education for individuals as well as societies as a whole is-mostly_uncontested. Both are desirable "assets" that seem to be important in order to live/provide a "good" life. However, when it comes to the relationship between the two, matters can get complicated. What role do (and should) economic developments/arguments play in public education? To what extent must or mustn't education align with economic requirements? The sixth issue of on_education aims at exploring the relationship between money and education from diverse perspectives.

Keywords: editorial, money, privatization

In capitalism, the significance of both money and education for individuals as well as societies as a whole is-mostly-uncontested. Both are desirable "assets" that seem to be important in order to live/provide a "good" life. However, when it comes to the relationship between the two, matters can get complicated. What role do (and should) economic developments/arguments play in public education? To what extent must or mustn't education align with economic requirements? The sixth issue of on_education aims at exploring the relationship between money and education from diverse perspectives. Two topics, "human capital theory" and "private schooling/elite education", serve as examples to raise questions allowing for controversial answers.

First, the idea of education as "human capital" that improves productivity (e.g. Becker, 1964; Schultz, 1961) and yields positive rates of return relates to economic motifs to invest in education. Prominent is the argument of Nobel Prize winner James Heckman (Heckman \& Masterov, 2007) who claims to provide evidence for the need to invest mostly in early childhood education for disadvantaged population groups as this yields the highest rate of return. As a "social investment strategy" (Esping-Andersen, 2002), this idea also finds its way into the design of welfare states. Such a utilitarian understanding of education (Biesta, 2018) gives rise to the following questions: Who should invest in which kind of education and why? Is it irresponsible to use public money for everyone's education without measuring its use against standards of efficacy and efficiency and holding organizations and individuals as recipients responsible? And what happens if education is no longer considered to be profitable by individuals, companies or states?

The second example that opens up to heated debates is any kind of elite education and private schooling. Many regard the notion that certain individuals or population groups are able to buy more and better education to be improper (Maxwell, Deppe, Krüger, \& Helsper, 2018). Theories of social justice emphasize that the distribution of a valuable good like education must not depend on the distribution of another valuable good like money (e.g. Walzer, 1983). However, what if the 
existence of private organizations improves the overall quality of an education system and thereby benefits all (Wößmann, Lüdemann, Schütz, \& West, 2009)? Should any kind of education that people can buy additionally at private expense (e.g. private tuition) be de-legalized? Moreover, looking at it the other way around, should we consider instances where better education leads to better employment opportunities and higher incomes as illegitimate discrimination?

Many additional topics might serve as good examples for the complicated relationship between money and education, e.g. corporate involvement in the public education system, economics education in schools or the historical development of public education in different types of economies. There are even more questions that need to be asked (e.g., Is sponsoring a valuable form of education funding? In what way is the investment of businesses in their employees' education different form corporate engagement with students as potential future employees? Which economic preconditions allow for public education?) The respective assessment of the "money-educationrelationship" will differ depending on the level of observation (individuals, organizations or states), on the disciplinary embeddedness of the observer (economics, social sciences, education, philosophy, politics) as well as on his or her field of activity (politics, practice, research) and cultural context.

The following contributions are a good beginning to explore a complex relationship from different points of view and hopefully provoke a noisy debate. Donald Gillies starts this issue off by critically discussing recent EU education policies that put education at the heart, but he finds them to be merely economically motivated. Following Amartya Sen, he raises the question what economic growth is actually good for, i.e. what legitimizes pursuing it through education.

In the second contribution, Nicole Klinkhammer and Felix Berth do not generally question the idea of investments in human capital but challenge the success of current implementations of respective policies. They argue that investments in early childhood education especially for disadvantaged children—which are supposed to yield the greatest rate of return—can only work if these children have access to high quality services.

High quality education certainly needs sufficient funding. However, in the third contribution Natasha Ridge argues that one should have a closer look at where the money comes from and whom to trust with the education of children. More precisely, she wonders at the mingling of "good guys" and "bad guys" at the Global Education and Skills Forum (GESF) and brings up the question in how far certain actors that are supposed to stand for free quality education for all fit into an event that is organized and funded by a Foundation that does not represent these values.

Two further contributions focus on higher education. First, Christopher Martin takes up a recent publication of Bryan Caplan who proposes that higher education does not contribute much to human capital building but mostly serves as a signal for already existing skills and dispositions of individuals. Christopher Martin discusses some of the central arguments of this publication and especially challenges the recommendations Caplan deduces from it.

Finally, Maggie Berg and Barbara K. Seeber turn the readers' attention to the consequences of using neoliberal language in relation to education. They are concerned with the inconsistence of a "metric fixation" with access and equity values as well as its consequences for complex intellectual activities and intellectual life at universities in general. 
The Editorial Team

References

Becker, G. S. (1975). Human capital: A theoretical and empirical analysis, with special reference to education. Chicago: The University of Chicago Press.

Biesta, G. (2018). Challenging utilitarianism. An interview with Gert Biesta. In N. Katznelson, N. U. Sorenson, \& K. Illeris (Eds.), Understanding learning and motivation in youth: Challenging policy and practice (pp. 56-63). Milton Park: Routledge.

Esping-Andersen, G. (2002). Why we need a new welfare state. Oxford: Oxford University Press.

Heckman, J. J., \& Masterov, D. V. (2007). The productivity argument for investing in young children. Applied Economic Perspectives and Policy, 29(3), 446-493. doi:10.1111/j.1467-9353.2007.00359.x

Maxwell, C., Deppe, U., Krüger, H.-H., \& Helsper, W. (Eds.) (2018). Elite education and internationalisation. From the early years to higher education. Basingstoke: Palgrave Macmillan.

Schultz, T. W. (1961). Investment in human capital. American Economic Review, 51(1), 1-17.

Wößmann, L., Lüdemann, E., Schütz, G., \& West, M. R., (2009). School accountability, autonomy, and choice around the world (Ifo Economic Policy series). Cheltenham: Edward Elgar.

\section{Recommended Citation}

Editorial Team (2019). Exploring the relationship of money and education. On Education. Journal for Research and Debate, 2(6). https://doi.org/10.17899/on_ed.2019.6.0

\section{Download PDF version}

Do you want to comment on an article or the whole issue? Please send your reply to editors@oneducation.net. Replies will be processed like invited contributions. This means they will be assessed according to standard criteria of quality, relevance, and civility. Please make sure to follow editorial policies and formatting guidelines. 